\title{
Experimental occlusion of the central artery of the retina. IV: Retinal tolerance time to acute ischaemia*
}

\author{
SOHAN SINGH HAYREH AND THOMAS A. WEINGEIST \\ From the Department of Ophthalmology, University of Iowa, Iowa City, USA
}

\begin{abstract}
SUMMARY Ophthalmoscopic, fluorescein angiographic, electrophysiological, and morphological studies on 63 eyes of rhesus monkeys with acute transient experimental occlusion of the central artery of the retina (OCAR) showed that the retina suffered irreparable damage after ischaemia of 105 minutes but recovered well after ischaemia of 97-98 minutes. The tolerance time of the brain to acute transient ischaemia is many times shorter than that of the retina. The metabolism of ischaemic neurones (in the retina and brain) is discussed with a view to explaining this difference, and also the various factors possibly responsible for the retina's longer tolerance of ischaemia, as compared to the brain.
\end{abstract}

Occlusion of the central artery of the retina (OCAR) is a true ophthalmic emergency, when every minute that elapses increases the chances of death of the retina. It is therefore absolutely essential to know how long it takes for acute retinal ischaemia to produce irreversible damage. Much of the confusion about this length of time is due to the many conflicting claims reported in anecdotal clinical case studies and in animal experiments, so that it is not at all surprising that in spite of the considerable interest which this subject has attracted no definite conclusion has been reached so far.

\section{Previous studies}

\section{CLINICAL CASE REPORTS}

Table 1 comprises most of the available reports in the English literature plus a few from other languages. Recovery of retinal function is said to take place after an ischaemia of anything from 10 minutes to as much as 36 hours. In addition there are 2 more reports in which slow recovery of vision after OCAR has been described. Story ${ }^{9}$ in 1899 described 2 such cases. A 35-year-old man suddenly lost vision in the left eye to light perception (LP) which improved to counting of fingers (CF) and to

\footnotetext{
*A brief summary of a part of this paper formed a part of the paper presented at the American Academy of Ophthalmology meeting on 7 November 1979 in San Francisco.
}

Correspondence to Dr S. S. Hayreh, Department of Ophthalmology, University of Iowa Hospitals and Clinics, Iowa City, lowa 52242, USA.
$6 / 24$ after 16 and 24 days respectively, and to $6 / 9$ and $6 / 6$ after 43 and 112 days respectively, with an ophthalmoscopically normal fundus. And a 39-yearold woman, who suddenly lost vision in the left eye, recovered to CF in 7 days and to $6 / 9$ in 32 days. Werner ${ }^{10}$ described a 27 -year-old syphilitic woman who, when seen 14 days after a sudden loss of vision in the left eye, was considered to have classical ophthalmoscopic findings of OCAR and doubtful LP. One week later the vision was LP in the superior nasal quadrant. One week after that she suddenly lost vision in the right eye with OCAR and was found to have doubtful LP in the right eye and $C F$ in the left eye. The visual acuity in the left eye improved to 6/9 42 days after the occlusion and in the right eye to $6 / 12$ and 6/9 14 and 20 days after the occlusion.

\section{EXPERIMENTAL STUDIES}

These are summarised in Table 2. There is a good deal of inconsistency in the results obtained, one report alleging irreversible retinal damage within 3 minutes, while in others much longer was needed. The relevance of those findings to clinical OCAR in man is open to criticism because of the following limitations in most of these studies.

Some of the animals used in these studies are not suitable for such an investigation; for example, rabbits have virtually no retinal circulation and the retina depends almost entirely for its nutrition on the choroidal circulation; cats have no central artery of the retina. The retinal ischaemia in these experiments was mostly produced by raising the 
Table 1 Previous clinical case reports of OCAR and recovery of vision

\begin{tabular}{|c|c|c|c|c|c|c|}
\hline Author & Year & $\begin{array}{l}\text { No. } \\
\text { of } \\
\text { eyes }\end{array}$ & $\begin{array}{l}\text { Duration of } \\
\text { ischaemia } \\
\text { (hours) }\end{array}$ & $\begin{array}{l}\text { Visual } \\
\text { recovery } \\
\text { to }\end{array}$ & Age & Cause of OCAR \\
\hline Mauthner ${ }^{1}$ & 1868 & 1 & $1 \frac{1}{2}$ & Normal & - & Embolus \\
\hline Wood-White 2 & 1882 & 1 & About 1 & $6 / 6$ & 31 & Embolus \\
\hline Mules $^{3}$ & 1888 & 1 & 1 & Normal & 21 & Embolus in inferior retinal artery \\
\hline Wagenmannt & 1898 & 1 & $1 / 6$ & Normal & - & Spasm \\
\hline Young $^{5}$ & 1932 & 1 & About 36 & Normal & 70 & Embolus \\
\hline Orr and Young ${ }^{8}$ & 1935 & 1 & $19 \frac{1}{2}-27$ & Normal & - & Embolus in inferior temporal branch artery \\
\hline \multirow[t]{13}{*}{ Watson ${ }^{2}$} & 1969 & 1 & $1 / 4$ & $6 / 5$ & 78 & Arteriosclerosis \\
\hline & & 1 & $1 / 2$ & $6 / 9$ & 53 & Embolus \\
\hline & & 2 & 2 and $2 \frac{1}{2}$ & $6 / 4$ & 25 & Orbital fracture \\
\hline & & 1 & $4 \frac{1}{2}$ & $6 / 12$ & 18 & Not known \\
\hline & & 1 & 6 & $6 / 36$ & 65 & Mild hypertension \\
\hline & & 1 & 8 & HM & 75 & Arteriosclerosis \\
\hline & & 1 & 9 & $6 / 18$ & 64 & Thrombotic thrombocytopenic purpura \\
\hline & & 1 & 13 & $6 / 36$ & 42 & Embolus \\
\hline & & 1 & 14 & $6 / 18$ & 18 & Not known \\
\hline & & $:$ & 15 & CF & 65 & Not known \\
\hline & & 1 & 24 & HM & 26 & Not known \\
\hline & & 1 & 27 & $6 / 60$ & 75 & ? Giant cell arteritis \\
\hline & & 1 & 36 & $6 / 60$ & 66 & Mild hypertension \\
\hline Younge and Rosenbaum ${ }^{8}$ & 1978 & 1 & 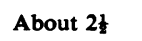 & Normal & 21 & Embolus \\
\hline
\end{tabular}

CF $=$ counting fingers. $\mathrm{HM}=$ hand motion.

Table 2 Previous experimental reports of acute retinal ischaemia and retinal tolerance time to ischaemia

\begin{tabular}{|c|c|c|c|c|c|}
\hline Author & Year & $\begin{array}{l}\text { Experimental } \\
\text { animal }\end{array}$ & $\begin{array}{l}\text { Experimental method } \\
\text { to produce retinal } \\
\text { ischaemia }\end{array}$ & $\begin{array}{l}\text { Method used to } \\
\text { evaluate retinal } \\
\text { integrity }\end{array}$ & $\begin{array}{l}\text { Tolerance } \\
\text { time }\end{array}$ \\
\hline \multirow[t]{3}{*}{ Turnbull11 } & 1948 & Rat & Animal centrifugation & Histology & $<3 \min$ \\
\hline & & Rat & Section of CAR & Histology & $<4-5 \mathrm{hr}$ \\
\hline & & Rat & Asphyxiation of animal & Histology & $<3 \min$ \\
\hline Smith and Baird ${ }^{22}$ & 1952 & Rat & $\uparrow$ IOP $100 \mathrm{mmHg}$ & Histology & $15 \min$ \\
\hline Popp $^{13}$ & 1955 & Rabbit & $\uparrow$ IOP $160 \mathrm{mmHg}$ & ERG & $>60-<75 \mathrm{~min}$ \\
\hline Reinecke et al. ${ }^{14}$ & 1962 & Cat & $\uparrow$ IOP $125 \mathrm{mmHg}$ & Histology & $<1 \frac{1}{2} \mathrm{hr}$ \\
\hline Böck et al..$^{15}$ & 1963 & Human & $\uparrow$ IOP $200 \mathrm{mmHg}$ & ERG & $>60-<120 \mathrm{~min}$ \\
\hline Fujino and Hamasaki ${ }^{16}$ & 1967 & $\begin{array}{l}\text { Squirrel } \\
\text { Monkey }\end{array}$ & $\uparrow$ IOP to systolic BP & ERG and histology & $60-<90 \mathrm{~min}$ \\
\hline Hamasaki and Kroll17 & 1968 & $\begin{array}{l}\text { Squirrel } \\
\text { Monkey }\end{array}$ & $\begin{array}{l}\text { Nylon suture looped around } \\
\text { CAR in orbit }\end{array}$ & $\begin{array}{l}\text { ERG and optic tract } \\
\text { discharges }\end{array}$ & $>90-<210 \mathrm{~min}$ \\
\hline $\begin{array}{l}\text { Foulds and Johnson }{ }^{18} \\
\text { Johnson' }^{10}\end{array}$ & $\begin{array}{l}1974 \\
1974\end{array}$ & Rabbit & $\begin{array}{l}\uparrow \text { IOP } 10 \mathrm{mmHg} \text { above } \\
\text { systolic BP }\end{array}$ & $\begin{array}{l}\text { ERG and light and } \\
\text { electron microscopy }\end{array}$ & Up to $1 \mathrm{hr}$ \\
\hline Vassileva and Dabov²0 & 1976 & Rabbit & $\begin{array}{l}\uparrow \text { IOP to supra-arterial } \\
\text { level }\end{array}$ & $\begin{array}{l}\text { ERG and retinal glycogen } \\
\text { content }\end{array}$ & About $50 \mathrm{~min}$ \\
\hline Shay and Ames ${ }^{21}$ & 1976 & Rabbit & $\begin{array}{l}\text { Retina incubated in media } \\
\text { lacking oxygen and glucose }\end{array}$ & & $40 \mathrm{~min}$ \\
\hline
\end{tabular}


intraocular pressure to supra-arterial levels, which not only stops the retinal circulation but also stops the choroidal circulation-the latter almost never occurs in the usual clinical OCAR in man. In almost none of these studies was there any systematic evaluation of the retinal circulation by fluorescein angiography. Finally, the retinal integrity was evaluated by electroretinography (ERG) and/or by histology. Our studies have clearly shown that ERG is not an entirely reliable technique for assessing retinal function after OCAR because it does not give us any information about the functional status of the ganglion cells or of most of the inner retina, which is essentially the area involved by OCAR in man.

\section{Materials and methods}

Our studies of experimental OCAR in 63 eyes eliminate these limitations by: (1) use of the rhesus monkey, which has a central retinal artery, retinal vasculature, retina, and other anatomical and physiological features identical to man's; (2) transient clamping of the central artery of the retina (CAR) at its site of entry into the optic nerve without interfering with the rest of the ocular circulation $;{ }^{22}(3)$ systemic evaluation of the retinal circulation by fluorescein angiography before, during, and after clamping the CAR and by fundus ophthalmoscopy; ${ }^{22}$ (4) evaluating the functional integrity of the retina not only by ERG but also by visual evoked response (VER), because the latter gives us information about the function of the retinal ganglion cells, optic nerve fibres, and the rest of the retina ${ }^{9}$ and in a number of animals even by testing the vision $;^{23}(5)$ using not only histological but also electron microscopic techniques to evaluate the morphological status of the retina; ${ }^{24}(6)$ and finally, by using a large sample size (63 eyes) to discover the various biological variations in the response of retina to ischaemia.

Detailed accounts of our findings are given in the earlier papers of this series. ${ }^{22-24}$ Briefly these are as follows:

Ophthalmoscopic findings. ${ }^{22}$ These are summarised in Table 3. OCAR for up to 97-98 minutes did not produce significant permanent retinal or optic nerve damage except in 2 eyes (with OCAR for 75 minutes) which may represent a normal biological variation in response. However, OCAR for 105 minutes or more always produced irreversible permanent marked retinal and optic nerve damage.

Fluorescein angiographic findings. ${ }^{22}$ In all but 2 eyes with retinal ischaemia for up to 97-98 minutes the retinal circulation, after unclamping the CAR, remained perfectly normal throughout, with retinal
Table 3 Ophthalmoscopic appearance at the end of the follow-up period

\begin{tabular}{|c|c|c|c|c|c|}
\hline $\begin{array}{l}\text { Duration } \\
\text { of } \\
\text { ischaemia } \\
\text { (minutes) }\end{array}$ & $\begin{array}{l}\text { Follow-up } \\
\text { period } \\
\text { (weeks) }\end{array}$ & $\begin{array}{l}\text { No. } \\
\text { of } \\
\text { eyes }\end{array}$ & Retina & $\begin{array}{l}\text { Optic } \\
\text { disc }\end{array}$ & $\begin{array}{l}\text { Retinal } \\
\text { vessels }\end{array}$ \\
\hline $16-20$ & $12-22$ & 11 & .Normal & Normal & Normal \\
\hline \multirow[t]{2}{*}{75} & $1 / 2,4,22$ & 3 & Normal & Normal & Normal \\
\hline & 20 & 2 & $\begin{array}{c}\text { Atrophic } \\
++\end{array}$ & $\begin{array}{c}\text { Atrophic* } \\
++\end{array}$ & Normal \\
\hline 90 & $12-14$ & 3 & Normal & Normal & Normal \\
\hline 97-98 & $17-19$ & 4 & Normal & $\begin{array}{l}\text { Slight } \\
\quad \text { pallor* }+\end{array}$ & Normal \\
\hline 105 & $13-16$ & 4 & $\begin{array}{c}\text { Atrophic } \\
++1 \\
\text { normal- } \\
\text { looking }\end{array}$ & $\begin{array}{c}\text { Atrophic* } \\
+++\end{array}$ & Narrow \\
\hline $134-138$ & $13-14$ & 3 & $\begin{array}{c}\text { Atrophic } \\
+++\end{array}$ & $\begin{array}{c}\text { Atrophic* } \\
+++\end{array}$ & Narrow \\
\hline $270-280$ & $13-14$ & 3 & $\begin{array}{c}\text { Atrophic } \\
++-\end{array}$ & $\begin{array}{c}\text { Atrophic* } \\
+++\end{array}$ & Narrow \\
\hline
\end{tabular}

*Started after 2 weeks and maximum by 3 weeks.

Table 4 Pattern of recovery of ERG and VER after unclamping $C A R$

\begin{tabular}{|c|c|c|c|}
\hline \multirow{2}{*}{$\begin{array}{l}\text { Duration of } \\
\text { ischaemia } \\
\text { (minutes) }\end{array}$} & \multirow{2}{*}{$\begin{array}{l}\text { No. } \\
\text { of } \\
\text { eyes }\end{array}$} & \multicolumn{2}{|l|}{ Recovery time for } \\
\hline & & Normal ERG & VER present \\
\hline 90 & 6 & $5-40$ minutes & $1-3 \frac{1}{2}$ hours \\
\hline $97-98$ & 8 & $15-60$ minutes & Approx. 4 hours \\
\hline \multirow[t]{2}{*}{102} & 2 & 1,2 hours & $2 \frac{1}{2}, 4 \frac{1}{2}$ hours \\
\hline & 2 & $1 \frac{1}{2}, 3$ hours & No recovery \\
\hline \multirow[t]{2}{*}{105} & 2 & 17 minutes, $3 \mathrm{hr}$ & $>3 \frac{1}{2}$ hours $-<1$ day \\
\hline & 4 & $5,45,75 \mathrm{~min}, 1$ day & No recovery \\
\hline 135 & 6 & $\begin{array}{l}24,3,4 \text { hours, } \\
1 \text { day, } 1 \text { day, ? }\end{array}$ & No recovery \\
\hline 270 & 5 & b-Wave $\frac{1}{2}$ normal & No recovery \\
\hline
\end{tabular}

capillaries normally outlined and no other angiographic abnormality. In eyes with retinal ischaemia of 105 minutes or longer and in 2 eyes with 75 minutes' OCAR the retinal capillaries and retinal pigment epithelium showed some atrophic changes.

Electrophysiological findings. ${ }^{23}$ These are summarised in Table 4. These show that the ERG recovered to the normal level in all eyes with OCAR of up to 135 minutes, and the $b$ wave was half normal with normal a wave in eyes with OCAR for 270 minutes. In contrast to these findings, the VER recovered to normal in all eyes (except 2 ) with OCAR up to 97-98 minutes and in 2 of the 4 eyes with OCAR for 102 minutes; in the rest of the eyes, i.e., 2 eyes with OCAR for 75 minutes, 2 eyes with 102 minutes, and all with 135 and 270 minutes' ischaemia, the VER did not recover. All the animals with OCAR for 97-98 minutes in their right eye and followed up 
for 3-4 months had their normal left eye completely closed by a tarsorrhaphy; after this procedure the animals were found to behave normally, as if their vision had recovered in the right eye.

Morphological findings. ${ }^{24}$ Light and electron microscopic studies revealed that OCAR for 105 minutes or longer resulted in irreversible damage to the inner part of the retina, including the inner two-thirds of the inner nuclear layer; the photoreceptors and outer part of the retina, including the outer one-third of the inner nuclear layers, were normal. The retina showed regional differences in susceptibility to ischaemia, the macular region being the most susceptible, the perimacular region less so, and the peripheral retina least of all. Differential susceptibility to ischaemia was also observed among various organelles and cells of the retina. Among the cytoplasmic organelles the mitochondria were found to be most susceptible, with microtubules and endoplasmic reticulum less so in descending order; the nuclei were the least susceptible of all. Among the retinal cells the ganglion cells were more susceptible than the bipolar cells, with Müller cells and astrocytic glia less susceptible, and the pericytes and endothelial cells of the vessels relatively resistant to ischaemia. The optic nerve showed atrophic degeneration of the nerve fibres. Eyes with OCAR for 97-98 minutes or less showed no appreciable permanent morphological damage in the retina and optic nerve.

\section{Discussion}

The data on our above-mentioned 4 types of findings ${ }^{22-24}$ were analysed separately by the 3 different investigators and collated only at the end. It was most interesting that all of us arrived at virtually the same conclusion, that is, the retina can tolerate acute ischaemia for up to 97-98 minutes with full recovery in all eyes, with rare exceptions. All eyes with OCAR for 105 minutes or more suffer irreparable damage. Half of the eyes with 102 minutes' OCAR recovered visual function.

Our findings conflict with many of the anecdotal clinical reports (Table 1) and experimental reports (Table 2). The clinical reports by Mauthner, ${ }^{1}$ Wood-White, ${ }^{2}$ Mules, ${ }^{3}$ Wagenmann, ${ }^{4}$ and 2 by Watson $^{7}$ (Table 1) agree with our findings. One of us (S.S.H.) saw a patient with OCAR who consulted an ophthalmologist and had his normal vision restored by a massage and paracentesis about 90 minutes after the onset of the visual loss. The patient has been followed up for $2 \frac{1}{2}$ years with normal visual fields and a visual acuity of $6 / 6$. The present study casts serious doubt on the case reports of recovery of vision many hours and even days and weeks after the onset of OCAR. It could be argued that in these patients there was sufficient residual retinal circulation after OCAR to protect against ischaemia; we investigated this topic particularly. Our findings were that there was no well-defined correlation between the amount of small residual retinal circulation and the severity of retinal damage. This subject is discussed in detail in Part I of this series. ${ }^{22}$ The discrepancies between the present study and some of the previous experimental studies (Table 2) may be due to the several limitations in those studies discussed above.

\section{TERMINOLOGY}

In connection with this subject it may be useful to distinguish the many terms used in the literature, e.g., survival time, recovery time, and tolerance or endurance time. Our definitions are as follows:

Survival time is the period during which after the onset of ischaemia there is still demonstrable function. (This has been reported as 4-5 minutes in rabbits $^{13}$ and $5-15$ seconds in man;25 26 this was not investigated in the present study.)

Tolerance or endurance time is the period of ischaemia after which function recovers completely, e.g., 97-98 minutes in our study.

Recovery time is the time taken by the retina to recover normal function after the restoration of normal circulation; this varied with the duration of ischaemia in our studies (Table 4), being about

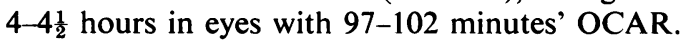

In the literature these terms are used interchangeably and confusingly.

COMPARISON OF THE TOLERANCE TIME TO ISCHAEMIA BETWEEN THE RETINA AND THE B R A I N

The findings of the present study also raise another very important question. In the brain permanent neuronal damage has been reported after ischaemia of $3 \frac{1}{2}$ (in cats $^{27}$ ) to over 6 minutes (in $\operatorname{dogs}^{28}$ ), though recovery of some neuronal functions in cats had been reported 30 minutes after cardiopulmonary arrest. ${ }^{29}$ In man cardiac arrest lasting for 3 minutes leads to permanent brain damage at $37^{\circ} \mathrm{C}$, but at $28^{\circ} \mathrm{C}$ the brain withstands cardiac arrest for up to $7 \frac{1}{4}$ minutes. ${ }^{30}$ Bourne $^{31}$ concluded that cerebral ischaemia of up to 2 minutes is followed by full recovery, but even a small extension of this time produces permanent damage. Meyer $^{32}$ recorded extensive neuronal necrosis in man following cardiac arrest under anaesthetic with ischaemia of 1 minute.

However, according to Garcia et al..$^{334}$ although it has been held traditionally that ischaemia of a few 
minutes' duration is lethal to brain tissue, the statement is not based on data derived from experimental scrutiny. Their biochemical and ultrastructural observations suggest that not only can mammalian brain seemingly endure prolonged incomplete ischaemia, but a serious breakdown of the system occurs only roughly 5 hours after the initial stroke.

It could well be argued that OCAR alone in man and primates represents an incomplete ischaemia of the retina, because the choroidal circulation remains normal and is not comparable to the complete global ischaemia of the brain. Experimental increase of intraocular pressure to above the arterial blood pressure level stops all intraocular circulations and produces 'global' retinal ischaemia and is comparable to the 'global' brain ischaemia. However, the available evidence (Table 2) does indicate that the retinal tolerance time to acute ischaemia is almost identical whether the ischaemia is produced by clamping the CAR alone (with normal choroidal circulation) or by raising the intraocular pressure to above the level of the arterial blood pressure (with arrest of both retinal and choroidal circulations).

In spite of the above mentioned findings by Garcia and others, clinical findings in man with complete global brain ischaemia and irreparable loss of cortical functions after about 3-7 minutes $^{27} 283^{30-32}$ indicate that the tolerance time of the brain to ischaemia seems to be many times shorter than the retina's, though it has a similar neural structure. Naturally the question arises, why? To understand some of the factors responsible for this difference, it is essential to understand the mechanism of ischaemic damage to the neural tissue, which has been summarised very well by Dixon. ${ }^{35}$

METABOLISM OF ISCHAEMIC NEURONES For normal functioning, neural tissue requires 2 cardinal nutrients: glucose and an adequate supply of oxygen. There is considerable evidence that ATP and creatine phosphate (CrP) are the major highenergy compounds generated from respiration and glycolysis. ${ }^{35}$ Ischaemia rapidly depletes the neurone of its stores of these compounds, thereby depriving the cells of the chemical energy so essential for maintaining both the electrical and synthetic activity of the cell. Aerobic oxidation can effect the synthesis of about 20 times as much ATP as is formed during anaerobic catabolism of the same quantity of sugar. Within about 10 seconds after the onset of complete ischaemia the oxygen of the brain is entirely consumed, leading to a sudden switch to anaerobic metabolism. It is supposed that the loss of consciousness in ischaemia is due to the fact that the cells do not have an adequate supply of energy under anaerobic conditions. The most critical initial loss, therefore, is lack of oxygen and not of glucose.

METABOLISM OF ISCHAEMIC NEURONES IN THE RETINA

All the available studies on the subject have been conducted in rabbits only. Weiss ${ }^{36}$ investigated the glycolysis in retinal ischaemia in rabbits. He found that rabbit retina normally has $0.05 \mathrm{mg}$ glucose and $0.35 \mathrm{mg}$ glycogen and the vitreous has $1.0-1 \cdot 1 \mathrm{mg}$ glucose and no glycogen, i.e., the glucose content of the vitreous is nearly 3 times higher than that of the retina. However, Wassilewa et al. ${ }^{37}$ did find glycogen in the vitreous of rabbits (mean value of $350 \mu \mathrm{mol} /$ $100 \mathrm{~g}$ in vitreous as compared to $2780 \mu \mathrm{m} / 100 \mathrm{~g}$ in the retina). In retinal ischaemia produced by raising the intraocular pressure to supra-arterial blood pressure levels Weiss ${ }^{36}$ described the following changes: "in the first 15-20 minutes of pressure ischaemia, the carbohydrate was taken up exclusively from the glycogen reserve of the retina. During the period of 20-40 minutes the glycogen content of the retina showed only a diminished decrease, about $30 \%$ of the value during the first 20 minutes. The reduction of the vitreous body glucose began simultaneously. It ranged within approximately the same limits as the utilisation of retinal glucose during the first 15-20 minutes. During the 40- to 70-minute period after the start of pressure ischaemia, the glucose reserve of the vitreous body was the only energy source for the glycolytic activity of the retina. Experiments extending beyond 70 minutes showed only slight sugar utilisation. When the experiment was extended to 2 hours, no significant difference was demonstrable between values after 90 and 120 minutes'.

If glucose-utilisation is taken as the indicator of anaerobic glycolysis in this experiment, then anaerobic glycolysis decreased during prolonged ischaemia. If it is assumed to be $100 \%$ in the first $15-20$ minutes, it is $80-90 \%$ from $20-40$ minutes, $70 \%$ from $40-60$ minutes, $50 \%$ at 70 minutes, and $20-30 \%$ at 90 minutes' ischaemia. On restoration of retinal circulation after 1 hour of ischaemia the glucose of the vitreous remained constantly low in the first 30 minutes. One hour after the end of ischaemia it was replenished $80-90 \%$, and an hour later it was normal. However, retinal glycogen was not replenished in this period, and only 2 days after the ischaemia did the glycogen reserve of the retina begin to renew itself; it was normal 24-36 hours after that. Intravenous administration of glucose did not affect the replenishment of retinal glycogen content in rabbits. These studies of Weiss ${ }^{36}$ in rabbits showed that glucose taken anaerobically 
from the vitreous is used up exclusively by the retina. He concluded that it is not the retinal glycogen but the glucose of the vitreous that must be regarded as the most important energy carrier in the retinal ischaemia lasting more than 20 minutes, and the exhaustion of the anaerobic glycolysis is one of the most essential factors determining the limits of tolerance time of the rabbits' retina. Ames and Gurian ${ }^{38}$ and Webster and $\mathrm{Ames}^{3 \mathrm{~B}}$ in incubated isolated rabbit retina found that either anoxia or glucose withdrawal alone produced less marked electrophysiological and electron microscopic changes than those produced by deprivation of both. Kaskel et al. ${ }^{40}$ found that several intermediates of glycolysis were changed in their concentrations after pressure ischaemia of rabbit retina, indicating a shift from aerobic to anaerobic breakdown of carbohydrate. The high consumption of glucose in anaerobic glycolysis results in higher consumption of glycogen. $^{37}{ }^{40}$ Vassileva and Dabov $^{20}$ found in rabbits that after 60-70 minutes' ischaemia complete replenishment of retinal glycogen did not occur, indicating irreversible change in the activity of enzymes which synthesise glycogen from blood glucose; they emphasised the great significance of glycogen in the retinal metabolism. Johnson ${ }^{41}$ found no glycogen in the Müller cells after 45-60 minutes' ischaemia in rabbits. Wassilewa et al. ${ }^{37}$ found reduction in vitreous glycogen as well, though much less than in the retina. Oberhoff and Hockwin ${ }^{42}$ found that ATP content of the retina was decreased by $40 \%$ after 1 hour's pressure ischaemia in cat and rabbit eyes, and they assumed glycogen to be an energy store for the retina.

The suggestion that NAD + concentrations may be of rate-limiting significance in the retina as well as in the brain is indicated by a related study of experimental microembolism in the miniature pig by Bardy and Tsacopoulos. ${ }^{43}$ They found, histochemically, that oxidation reduction systems utilising NAD were not detectable following ischaemia. These authors also found a pH drop in the retina to $7 \cdot 19$ and then to 7.01 after 10 minutes. They ascribed this to diffusion into the retina of lactate accumulated in the vitreous. They speculated that this decrease in $\mathrm{pH}$ results in decrease in the activity of the phosphofructokinase system, a rate-limiting step in glycolysis, and eventually to cessation of cell function.

Although much more remains to be learned about the biochemical metabolic changes in the ischaemic retina, it is certain that an adequate supply of glucose and oxygen is vital for the normal functioning of the retina and that glycolysis is essential for its survival.
FACTORS RESPONSIBLE FOR MUCH LONGER TOLERANCE TIME TO ISCHAEMIA BY THE RETINA THAN THE BRAIN

Probably the following factors have an important role.

(1) The findings of Weiss ${ }^{35}$ and others ${ }^{37-43}$ may help to explain the fact that the tolerance time of the retina is many times longer than that of the brain during ischaemia. The brain has very scanty stores of intracellular glucose and depends entirely on the blood circulation to supply constantly not only oxygen but also glucose. In contrast to that, in the retina, the situation is very different because (i) there is an ample store of glucose and glycogen, (ii) in addition, the vitreous's glucose content is nearly 3 times that of the retina, and (iii) probably the most important factor is that the major part of glucose and oxygen $(80 \%$ and $60 \%$ respectively in pigs, and $80 \%$ of oxygen in cats ${ }^{44}$ ) consumed by the retina ordinarily is delivered by the choroidal vessels. ${ }^{45}$ This gives the retina self-sufficiency in glucose, and to some extent in oxygen, for a much longer time than the neurones in the brain. Weiss ${ }^{36}$ found that in the rabbit retina, after 1 hour of ischaemia, there was still $0.15 \mathrm{mg}$ of glycogen in the retina $(0.35 \mathrm{mg}$ in normal retina) and $0.60-0.65$ $\mathrm{mg}$ glucose in the vitreous (1.0-1.1 $\mathrm{mg}$ normally). However, other similar studies in rabbits reported complete loss of glycogen in the retina following 45-60 minutes of ischaemia. ${ }^{203741}$ The immediate loss of function in the retina (blindness) and in the brain (loss of consciousness) seem to be due to the deprivation of oxygen and show no difference between the 2 tissues.

(2) No-reflow phenomenon in ischaemic brain: The no-reflow phenomenon is the most accepted current view explaining the irreversible brain damage after a transient brain ischaemia. Development of marked oedema of the neural tissue in acute ischaemia is a well-known phenomenon. When this occurs in the brain, firstly the rigid cranial cavity cannot accommodate the extra volume produced by the oedema, and, secondly, since the brain as an organ is composed of thick, solid tissue, the deeper parts of the brain have no place to expand to in the surrounding solid, swollen tissue. Those 2 factors combine to cause obliteration of the microvasculature (since the vascular structures are the only pliable tissue which will yield and collapse as the neural tissue expands). This secondary vascular occlusion effectively prevents the return of the blood supply even if the circulation is quickly restored. The other factors which probably contribute to the no-reflow phenomenon in the brain are increased blood viscosity resulting from a shift of fluids from the extracellular to intracellular phase, ${ }^{46}$ intravas- 
cular sludging and clotting, ${ }^{47}$ postischaemic rise in intracranial pressure, ${ }^{48}$ and postischaemic hypotension. ${ }^{49}$ Ames et al. $^{46}$ and others have shown that this local perfusion defect on restoration of circulation to the neural tissue (which may still be viable) produces irreversible damage.

The retina, on the other hand, is a very thin membrane set in surroundings which can accept oedema easily and regulate its pressure without compromising the retinal microvasculature, so that the phenomenon of no-reflow does not exist in the ischaemic retina. Hence the striking difference in tolerance times between the brain and the retina. It is conceivable that, if the neural tissue of the brain had a similarly favourable environment it could survive for a much longer time than it does.

(3) The other factor responsible for the retina's much greater tolerance of ischaemia than the brain's may be the difference in susceptibility to ischaemic damage by different types of neurones, as seen in the brain. ${ }^{27}$ It is possible that the retinal neurones are more resistant to ischaemia than the neurones in the brain. Our studies ${ }^{24}$ have shown that within the retina itself there is a differential susceptibility to ischaemic damage (vide supra). One of the possible reasons for the differential susceptibility between the different neurones may be the amount of protein turnover in a particular neurone. It has been shown that ischaemia inhibits cerebral protein synthesis, ${ }^{5051}$ and this could explain the early and selective enzyme loss in certain areas of the brain. If an area has a high rate of protein turnover, it would be more susceptible to ischaemia. This would be especially true if increased proteolysis occurred, catalysed by lysosomal proteases released by cell destruction. ${ }^{52}$

(4) Importance of the vitreous as a reserve source of oxygen for the retina: It could be argued that oxygen in the vitreous may play some role in the prolonged tolerance of the retina to ischaemia. Dr Albert Alm (Uppsala, Sweden), from various studies by him and his group (Anders Bill, Per Tørnquist) on cats and pigs, calculated for us the amount of oxygen in the vitreous, which is most probably $2 \cdot 4 \mu \mathrm{l}$, corresponding to about $100 \mathrm{nmol}$ oxygen (A. Alm, personal communication). Since the oxygen consumption of one pig retina in vivo is about $300 \mathrm{nmol} /$ minute, the calculated oxygen in the vitreous could support normal retinal metabolism for about 20 second only. This would indicate that the vitreous can be disregarded as a significant source of oxygen in OCAR.

These are some possible reasons for the difference in the tolerance of ischaemia between the retina and brain, but there is much more to be learned before we can explain this mystery satisfactorily. This is an important subject, because a better understanding of it could give us clues to increasing the tolerance of ischaemia not only in the retina but also in the brain, and thus help us to buy time for resuscitating these organs after acute ischaemia.

We are grateful to Dr Gene F. Lata, associate professor of biochemistry, for his help with the biochemical discussion in this paper, and to Miss Karol Kratz for her secretarial help. This study was supported by the National Eye Institute grant No. EY-01576.

\section{References}

1 Mauthner L. Lehrbuch der Ophthalmoscopie. Vienna: Verlag von Tendler, 1868.

2 Wood-White EW. Embolism of arteria centralis: Reestablishment of circulation witnessed with ophthalmoscope. Ophthalmol Rev 1882; 1: 49-51.

3 Mules PH. On embolism of a branch of the central retinal artery treated by massage, with restoration of the visual field. Trans Ophthalmol Soc UK 1888; 8: 151-5.

4 Wagenmann A. Circulatory disturbances in the retinal vessels. Arch Ophthalmol 1898; 27 : 356-7.

5 Young G. Embolism of the central retinal artery. Br Med $J$ 1932; ii: 878.

6 Orr HC, Young JH. Acetylcholine in embolism of the retinal artery. Br Med $J$ 1935; i: 1119-20.

7 Watson PG. The treatment of acute retinal arterial occlusion. In: Cant JS, ed. The Ocular Circulation in Health and Disease. London: Kimpton, 1969: 234-45.

8 Younge BR, Rosenbaum TJ. Treatment of acute central retinal artery occlusion. Mayo Clin Proc 1978;51:408-10.

9 Story JB. Recovery of sight after a partial occlusion of the central artery. Trans Ophthalmol Soc UK 1899; 19: 87-93.

10 Werner LE. Bilateral obstruction of the central artery of the retina; complete restoration of vision. Trans Ophthalmol Soc UK 1931; 51 : 654-6.

11 Turnbull $\mathrm{W}$. The effects of experimental retinal anaemia in rats. Trans Can Ophthalmol Soc 1948; 11 : 116-34.

12 Smith GG, Baird CD. Survival time of retinal cells when deprived of their blood supply by increased intraocular pressure. Am J Ophthalmol 1952; 15: 133-6.

13 Popp C. Die Retinafunktion nach intraokularer Ischämie. Albrecht von Graefes Arch Klin Ophthalmol 1955; 156: 395-403.

14 Reinecke RD, Kuwabara T, Cogan DG, Weis DR. Retinal vascular patterns. Part V: Experimental ischemia of the cat eye. Arch Ophthalmol 1962; 47: 470-5.

15 Böck J, Bornschein H, Hommer K. Die Wiederbelebungszeit der menschlichen Netzhaut: Eine elektroretinographische Studie. Albrecht von Graefes Arch Klin Ophthalmol 1963; 165: 437-51.

16 Fujino T, Hamasaki DI. Effect of intraocular pressure on the electroretinogram. Arch Ophthalmol 1967; 78: 757-65.

17 Hamasaki DI, Kroll AJ. Experimental central retinal artery occlusion: an electrophysiological study. Arch Ophthalmol 1968; 88: 243-8.

18 Foulds WS, Johnson NF. Rabbit electroretinogram during recovery from induced ischaemia. Trans Ophthalmol Soc UK 1974; 94: 383-93.

19 Johnson NF. Effects of acute ischaemia on the structure of the rabbit retina. Trans Ophthalmol UK 1974; 94: $394-405$.

20 Vassileva PI, Dabov SB. Changes in the glycogen content and the electroretinogram in retinal ischaemia experi- 
mentally-induced in rabbits. In: Cant JS, ed. Vision and Circulation. London: Kimpton, 1976: 66-78.

21 Shay J, Ames A III. Retina subjected to components of ischemia in vitro. Arch Neurol 1976; 13: 715-21.

22 Hayreh SS, Weingeist TA. Experimental occlusion of the central artery of the retina-I. Ophthalmoscopic and fluorescein fundus angiographic studies. Submitted for publication.

23 Kolder HE, Weingeist TA, Hayreh SS. Experimental occlusion of the central artery of the retina-II. Electrophysiological studies. In preparation.

24 Weingeist TA, Hayreh SS. Experimental occlusion of the central artery of the retina-III. Morphological studies. In preparation.

25 Schubert G. Ein entoptisches Hypoxie-phänomen. Z Biol 1958; 110: 232-5.

26 Cibis P, Hochgeschurz G. Expeimentelle Untersuchungen über die Wirkung der durch künstliche Steigerung des intraokularen Druckes hervorgerufenen Ischämie auf die Funktion der Netzhaut. Albrecht von Graefes Arch Klin Ophthalmol 1948; 148: 752-60.

27 Weinberger L, Gibbon MH, Gibbon JH. Temporary arrest of the circulation to the central nervous system: I. Physiologic effects. II. Pathologic effects. Arch Neurol Psychiat 1940; 43: 615-34, 961-86.

28 Kabat H, Dennis C, Baher AB. Recovery of function following arrest of the brain circulation. Am J Physiol 1941; 112: 737-47.

29 Hossmann V, Hossmann K-A. Return of neuronal functions after prolonged cardiac arrest. Brain Res 1973; 60: 423-38.

30 Brock R. Hypothermia and open cardiotomy. Proc $R$ Soc Med 1956; 49: 347-52.

31 Bourne JG. Fainting and cerebral damage. A danger in patients kept upright during dental gas anaesthesia and after surgical operations. Lancet 1957; ii: 499-505.

32 Meyer A. Neuropathological aspects of anoxia. Proc $R$ Soc Med 1956; 49: 619-22.

33 Garcia JH, Lossinsky AS, Kauffman FC, Conger KA. Neuronal ischemic injury: Light microscopy, ultrastructure and biochemistry. Acta Neuropathol (Berl) 1978; 41 : 85-95.

34 Pence RS, Garcia JH. Tyrosine uptake and metabolism during regional cerebral ischemia. Circulation 1976; 54: 103 (Suppl. II).

35 Dixon KC. Ischaemia and the neurone. In: Adams CWM, ed. Neurohistochemistry. New York: Elsevier, 1965: 558-98.

36 Weiss $\mathrm{H}$. The carbohydrate reserve in the vitreous body and retina of the rabbit's eye during and after pressure ischaemia and insulin hypoglycaemia. Ophthalmol Res 1972; 1 : 360-71.

37 Wassilewa P, Hockwin O, Korte I. Glycogen concentra- tion changes in retina, vitreous body and other eye tissues caused by disturbances of blood circulation. Albrecht von Graefes Arch Klin Ophthalmol 1976; 199: 115-20.

38 Ames A III, Gurian BS. Effects of glucose and oxygen deprivation on function of isolated mammalian retina. J Neurophysiol 1963; 26: 617-34.

39 Webster H deF, Ames A III. Reversible and irreversible changes in the fine structure of nervous tissue during oxygen and glucose deprivation. J Cell Biol 1965; 26: 885-909.

40 Kaskel D, Hockwin O, Metzler U, Schedtler C-M. Glycogen content in the rabbit retina in relation to blood circulation. Ophthalmol Res $1973 ; 5$ : 177-85.

41 Johnson NF. Retinal glycogen content during ischaemia Albrecht von Graefes Arch Klin Ophthalmol 1977; 283: 271-82.

42 Oberhoff P, Hockwin O. The ATP content of the retina in relation to the blood circulation. Albrecht von Graefes Arch Klin Ophthalmol, 1969; 178: 329-32.

43 Bardy M, Tsacopoulos M. Modification metaboliques retiniennes après microembolisation artériolaire expérimentale chez le porc miniature. Klin Monatsbl Augenheilkd 1978; 172: 451-60.

$44 \mathrm{Alm}$ A, Bill A. The oxygen supply to the retina, II. Effects of high intraocular pressure and of increased arterial carbon dioxide tension on uveal and retinal blood flow in cats. Acta Physiol Scand 1972; 84: 306-19.

45 Tørnquist P. Aspects of Retinal Nutrition. Acta Universitatis Uppsaliensis. Uppsala: University of Uppsala, 1979: 326.

46 Ames A III, Wright RL, Kowada M, et al. Cerebral ischemia. II. The no-reflow phenomenon. Am J Pathol $1968 ; 52: 437-47$.

47 Hekmatpanah J. Cerebral blood flow dynamics in hypotension and cardiac arrest. Neurology 1973; 23: 174-80.

48 Hekmatpanah J. Cerebral circulation and perfusion in experimental increased intracranial pressure. $J$ Neurosurg $1970 ; 32: 21-9$.

49 Cantu RC, Ames A III, Di Giacinto G, et al. Hypotension: a major factor limiting recovery from cerebral ischemia. J Surg Res 1969; 9: 525-9.

50 Spector RG. Enzyme chemistry of anoxic brain injury. In: Adams CWM, ed. Neurohistochemistry. New York: Elsevier, 1965: 547-57.

51 Zeman W. In: Schade JP, McMenemy WH, eds. Selective vulnerability of the Brain in Hypoxaemia. Oxford, 1963: 327.

52 Yates CM, Reading HW, Bitensky L, Chayen J. The state of pigment epithelium lysosomes in the retina of normal rats and those with retinitis pigmentosa. Biochem $J$ 1970; 119: 57-8. 